\title{
The Rate of Asymptomatic Plasmodium Parasitemia and Placental Parasitization in Urban and Rural Areas of Cross River State, Nigeria
}

\author{
Cajethan Emechebe*(i), Andrew Enwa Okpe, Edu Michael Eyong, Charles Obinna Njoku \\ Department of Obstetrics and Gynecology, University of Calabar Teaching Hospital (UCTH), Calabar, Nigeria
}

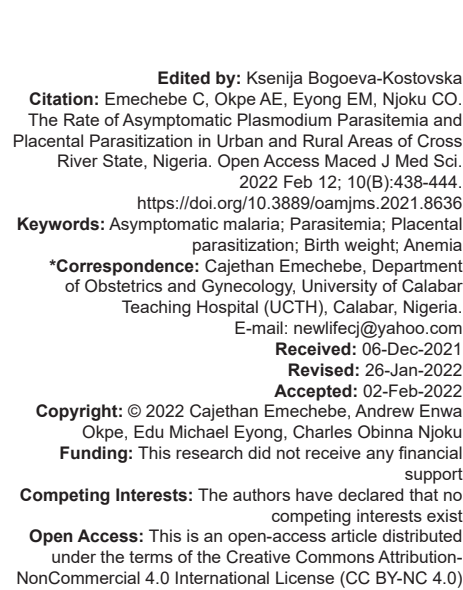

\section{Introduction}

Malaria is a key contributor to maternal morbidity and mortality especially in sub-Saharan Africa where the disease is endemic and one of the areas of focus of the just concluded millennium development goal [1]. Despite long-term global, regional and national efforts, an estimated 1-2 million die annually, mostly in sub-Saharan Africa with over one-tenth of maternal deaths in the region caused by malaria in pregnancy which is highly preventable [2]. Furthermore, infants born to mothers who had malaria during pregnancy have increased risk of morbidity and mortality such as impaired neurodevelopment, premature births, low birth weight, anemia, and subsequent congenital malaria [3], [4], [5]. Some long-term complications that may occur or persist even several years after maternal infection include increased risk of high infant blood pressure that may continue in adulthood and adverse effects on childhood neurodevelopment [5], [6].

Unfortunately, some of the predisposing factors such as the hot and humid equatorial climate that supports breeding of mosquito vectors are quite non-modifiable [7]. Some other predisposing factors are man-made, including poor environmental conditions and climate change, which may be associated with antimalarial drug resistance [4]. However, a key modifiable factor that may be responsible for high prevalence of malaria in pregnancy in sub-Saharan African region are poor maternal health care access and compliance with preventive measures such as good drainage and environmental sanitation [8]. Malaria vector control especially in equatorial sub-Saharan Africa has been quite difficult perhaps due to relative favorability of the humid climatic conditions to breeding [7]. Furthermore, changing climatic conditions over the decades may have contributed to increasing resistance of Plasmodium 
parasites to available antimalarial medications [9]. These challenges have left most malaria endemic settings with the cost-effective option of improving maternal health access for malaria prevention through prophylaxis and treatment [10].

One of the areas of reassessment is a better understanding of the pattern of occurrence of malaria parasite infection of blood and placenta as a reflection of vector exposure, as well as access and response to available prevention and treatment measures [11], [12]. Unfortunately, in the rain forest of the south-south region of Nigeria, where malaria is highly endemic, there is paucity of literature on pattern of "hidden" but harmful malaria parasite infection that may be detectable as placental malaria [11]. This study seeks to investigate this pattern through comparison of blood and placental infection. Improved understanding of pattern of asymptomatic malaria infection may be useful for improvement in the quality of prophylaxis, as well as individual and group counseling on malaria prevention provided during antenatal clinic visits. This study may also contribute to improvement in understanding of the socio-demographic, obstetric and other risk factors that may be associated with malaria infection despite prophylaxis, especially in endemic settings.

\section{Methodology}

\section{Study area}

This prospective study was carried out among pregnant women in University of Calabar Teaching Hospital (UCTH) Calabar (urban study site) and General Hospital Akamkpa (rural study site) both in southern senatorial district in Cross River State, Nigeria. The urban study site (Calabar) is the capital city of Cross River state in South-South Nigeria. It is a rainforest region with high annual rainfall and humidity [13]. There is poor and inadequate drainage of waste water, and common presence of surrounding bushes, with resultant high prevalence of breeding spots for the mosquito vectors. In the suburbs, there is substandard overcrowded housing, with little or no protection from mosquito vectors. The rural study site (Akamkpa) is also a rainforest region with high annual rainfall and humidity. The residents are mostly peasant farmers and is the largest local government area in the state, with a densely forest areas.

\section{Study population}

The study population consists of pregnant women admitted to the labor ward in UCTH, Calabar, and labor ward in General hospital, Akamkpa in Cross River State.

\section{Inclusion criteria}

Pregnant women with asymptomatic malaria during pregnancy and admitted to the labor ward for delivery in both health facilities were included in the study.

\section{Exclusion criteria}

Pregnant women with multiple gestation, HIV infection, clinical symptom of malaria in pregnancy and sickle cell disease, were excluded from the study.

\section{Sampling for urban and rural study sites}

A total of 220 samples of parturients were collected in urban site in UCTH. Systematic random sampling method was used to select parturients from the labor ward in UCTH. Sampling interval of three (3) was used based on estimated sample size and expected number of clients from previous records. A total of about 10 samples were taken weekly for the 22 weeks until the estimated sample size 220 in urban study site were attained. The parities of the samples in the urban site were recruited to match the parities of the samples in rural areas to reduce the effect of parities on malaria placental parasitization and parasitemia.

Furthermore, total of 220 samples of parturients were collected in rural site in Akamkpa general hospital. A total of about 10 samples were taken weekly for 22 weeks until the estimated sample size of 220 subjects in rural study site were attained.

Neonatal outcome measures that were assessed include birth weight, neonatal length and occipito-frontal circumference. Birth weights of the newborn were measured using a standard and validated neonatal weighing scale. Newborn with weight $<2500$ grammes was considered low birth weight. Infantometer was used to measure neonatal length from the crown to the heel. A flexible but non-stretchable tape was used to measure the occipito-frontal diameter.

\section{Study protocol}

Ethical clearance was obtained from the UCTH research ethics committee, as well as written informed consent obtained from subjects, before commencement of data collection. Interviewer assisted administration of structured questionnaire was used to obtain sociodemographic data and obstetric history. Thereafter, $4 \mathrm{mls}$ of maternal venous blood samples was obtained from subjects using labeled EDTA tubes. These samples were sent immediately to UCTH microbiology laboratory for independent estimation of hemoglobin and malaria parasite concentrations by thick and thin film. All the placental tissue samples were obtained by making a wedge-shaped $2 \mathrm{~cm} \times 2 \mathrm{~cm} \times 2 \mathrm{~cm}$ incision on the maternal side, fixed in $10 \%$ neutral buffered formalin 
and sent immediately to the hospital histopathology laboratory for assessment of parasitization by the histopathologists. Parasitization of placental tissue was classified as active, active-on-past (chronic), and past infections. Active infection is when parasites are present in the intervilleous space with or without pigment in the intervilleous monocytes. Chronic (activeon-past) infection is when the parasite are present in the intervilleous space along with pigments as deposits or in macrophages with fibrin while past infection is when pigment is presence in the absence of parasites. Active and chronic infections were used in this study as presence of plasmodium parasite in the placenta while past infection signified absence of parasites.

Determination of malaria parasite density was done using separately labeled thick and thin film blood smears prepared from samples obtained from maternal venous blood. The thick films were used to identify the presence of asexual stages of Plasmodium parasites. Parasite density or degree of infection was considered negative if no parasite is seen. Estimating the parasite number/ $\mu$ l of blood was done by counting parasites against white cells by selecting the part of the thick film where the white cells are evenly distributed and the parasites are well stained using the oil immersion. Number of parasite per $\mu$ l of blood $=$ white blood cells (WBC) count× parasite count against 100 WBC/100 [14].

\section{Results}

During the 6 months study period from $1^{\text {st }}$ August, 2018 to $31^{\text {st }}$ January, 2019, there were a total of 1346 deliveries in urban site (UCTH) and 782 deliveries over the study period in the rural site. The mean age of the participants in the study was $28.45 \pm 3.06$ years. The mean age in the urban site was $29.71 \pm 4.11$ years and the rural site was $26.8 \pm$ 3.43. The mean maternal hemoglobin concentration was $11.1 \mathrm{~g} / \mathrm{dl} \pm 2.43$.

Malaria parasitemia was most common among women of age group of 30-39 years 97 (54.8\%) and nulliparous women 76 (42.9\%). However, only parity was significantly associated with malaria parasitemia in urban and rural area $\left(\chi^{2}=14.35 ; p=0.006\right)$ (Table 1). For placental parasitization, higher prevalences were noted among the age group of 20-29 years, 159 (51.5\%) and para 0, 108 (35.0\%). However, age, parity and booking status were not significantly associated with risk of malaria placental parasitization in urban and rural areas.

\section{Prevalence of malaria parasitemia and} placenta parasitization among pregnant women

Out of 440 participants, 177 (40.2\%) were positive for malaria parasitemia while 309 (70.2\%) were positive for placenta parasitization. Based on residential status, 109 (49.5\%) rural residents had higher malaria parasitemia than their urban resident counterparts $68(30.9 \%)$ and the difference was statistically significant $(p=0.000)$ (Figure 1). The prevalence of placenta parasitization was found to be higher among rural residents $178(80.9 \%)$ than their urban resident counterparts $131(59.5 \%)$ and the difference was statistically significant $(p=0.000)$ (Figure 2).

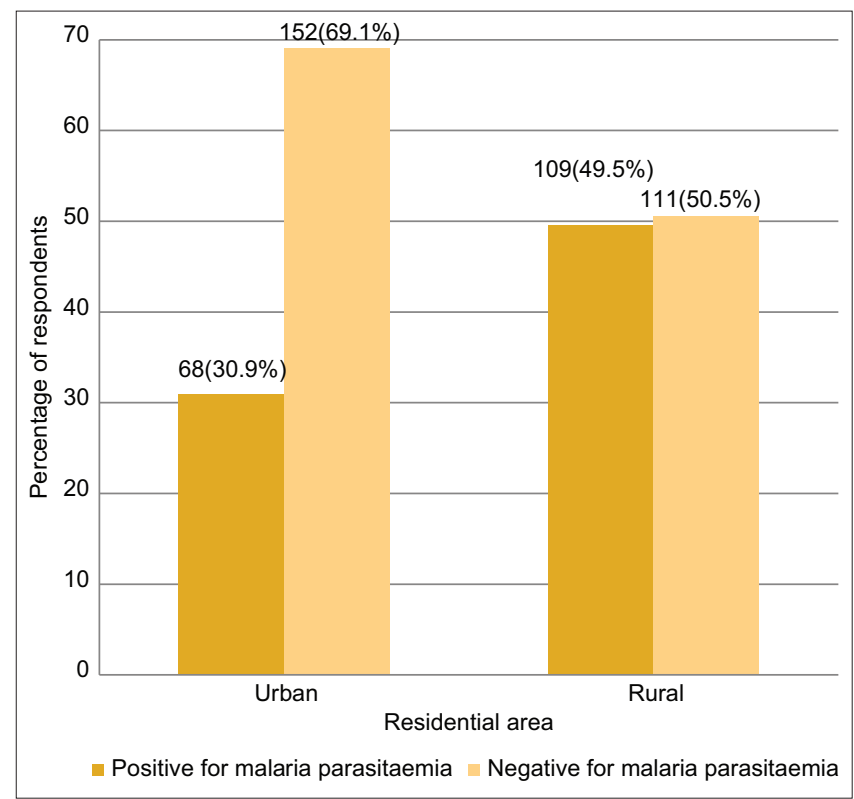

Figure 1: Prevalence of malaria parasitemia among pregnant women based on residential status

Preterm delivery was higher among pregnant women with positive placental parasitization (12.3\%) than pregnant women with negative placental parasitization $(5.3 \%)$ and the difference was statistically significant $\left(\chi^{2}=4.85 ; p=0.028\right)$ (Table 2$)$. Preterm delivery among women with positive placental malaria

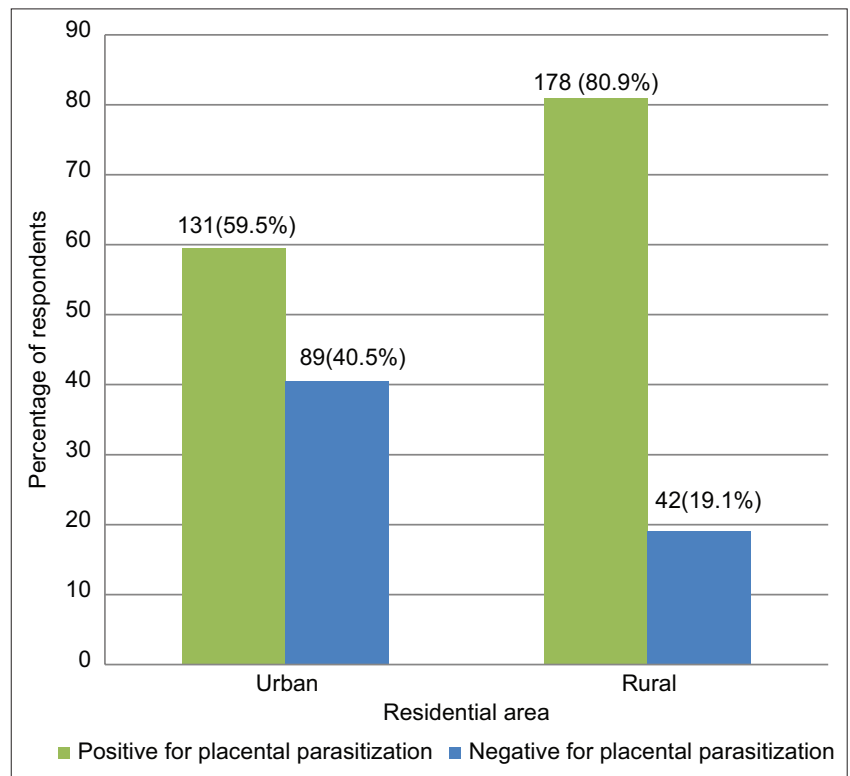

Figure 2: Prevalence of placental parasitization among pregnant women based on residential status 
Table 1: Socio-demographic characteristics of the respondents and rate of malaria parasitemia and placental parasitization

\begin{tabular}{|c|c|c|c|c|c|c|c|c|}
\hline \multirow[t]{3}{*}{ Variables } & \multicolumn{8}{|c|}{ Frequency (percentage) } \\
\hline & \multicolumn{4}{|c|}{ Malaria parasite in blood } & \multicolumn{4}{|c|}{ Placental parasitization } \\
\hline & Urban & Rural & Total & $\chi^{2}(p$-value $)$ & Urban & Rural & Total & $\chi^{2}(p$-value $)$ \\
\hline \multicolumn{9}{|l|}{ Age ( years) } \\
\hline $15-19$ & $2(2.9)$ & $6(5.5)$ & $8(4.5)$ & \multirow{4}{*}{$2.52(0.471)$} & $7(5.3)$ & $5(2.8)$ & $12(3.9)$ & \multirow{4}{*}{$3.29(0.348)$} \\
\hline $20-29$ & $21(30.9)$ & $43(39.5)$ & $64(36.2)$ & & $61(46.6)$ & $98(50.6)$ & $159(51.5)$ & \\
\hline $30-39$ & $41(60.3)$ & $56(51.4)$ & $97(54.8)$ & & $57(43.5)$ & $70(39.3)$ & $127(41.1)$ & \\
\hline $40-49$ & $4(5.9)$ & $4(3.7)$ & $8(4.5)$ & & $6(4.6)$ & $5(1.6)$ & $11(3.5)$ & \\
\hline \multicolumn{9}{|l|}{ Parity } \\
\hline 0 & $28(41.2)$ & $48(44.0)$ & $76(42.9)$ & \multirow{5}{*}{$14.35(0.006)^{\star}$} & $48(36.6)$ & $60(33.7)$ & $108(35.0)$ & \multirow{5}{*}{$1.33(0.856)$} \\
\hline 1 & $20(29.4)$ & $41(37.6)$ & $61(34.5)$ & & $41(31.3)$ & $59(33.2)$ & $100(32.4)$ & \\
\hline 2 & $3(4.4)$ & $9(8.3)$ & $12(6.8)$ & & $28(21.4)$ & $37(20.8)$ & $65(21.0)$ & \\
\hline 3 & $13(19.1)$ & $3(2.8)$ & $16(9.0)$ & & $12(9.2)$ & $18(10.1)$ & $30(9.7)$ & \\
\hline$\geq 4$ & $4(5.9)$ & $8(7.3)$ & $12(6.8)$ & & $2(1.5)$ & $4(2.2)$ & $6(1.9)$ & \\
\hline \multicolumn{9}{|l|}{ Educational status } \\
\hline No formal education & $5(7.4)$ & $16(14.7)$ & $21(11.8)$ & \multirow{4}{*}{$2.41(0.490)$} & $14(10.7)$ & $22(12.4)$ & $36(11.6)$ & \multirow{4}{*}{$6.22(0.101)$} \\
\hline Primary & $18(26.5)$ & $28(25.7)$ & $46(26.0)$ & & $40(30.5)$ & $42(23.6)$ & $82(26.5)$ & \\
\hline Secondary & $31(45.6)$ & $42(38.5)$ & $73(41.2)$ & & $62(47.3)$ & $76(42.7)$ & $138(44.7)$ & \\
\hline Tertiary & $14(20.6)$ & $23(21.1)$ & $37(20.9)$ & & $15(11.5)$ & $38(21.4)$ & $53(17.2)$ & \\
\hline \multicolumn{9}{|l|}{ Marital status } \\
\hline Married & $45(66.2)$ & $70(64.2)$ & $115(65.0)$ & & $104(79.4)$ & $133(74.7)$ & $237(76.7)$ & \multirow{4}{*}{$1.34(0.344)$} \\
\hline Single & $22(32.4)$ & $39(35.8)$ & $61(34.5)$ & $1.7(0.413)$ & $27(20.6)$ & $45(25.3)$ & $72(23.3)$ & \\
\hline Divorce & $1(1.5)$ & $0(0.0)$ & $1(0.5)$ & & $0(0.0)$ & $0(0.0)$ & $0(0.0)$ & \\
\hline Total & $68(38.4)$ & $109(61.6)$ & $177(100)$ & & $131(42.3)$ & $178(57.6)$ & $309(100)$ & \\
\hline
\end{tabular}

parasitization was higher in urban area $(13.0 \%)$ than the rural area $(11.8 \%)$ although, the difference was not statistically significant $\left(\chi^{2}=0.10 ; p=0.755\right)$. Low $5^{\text {th }}$ min Apgar score $(<7)$, low birth weight $(<2.5 \mathrm{~kg})$ and low neonatal length were significantly higher in pregnancy with positive placental parasitization than in women with negative placental malaria parasitization. Anemia was significantly higher in rural women with positive placental malaria parasitization $(29.8 \%)$ than urban women with positive placental malaria parasitization $(12.2 \%)\left(\chi^{2}=13.42 ; p=0.000\right)$. Low $5^{\text {th }}$ min Apgar score was significantly higher in rural women with positive placental malaria parasitization $(23.0 \%)$ than urban women with positive placental malaria parasitization $(7.6 \%)\left(\chi^{2}=12.99 ; p=0.000\right)$.

\section{Obstetric outcome of patients with positive} and negative malaria parasitemia

Preterm delivery was higher among pregnant women with positive malaria parasitemia $(22.6 \%)$ than pregnant women with negative malaria parasitemia
$(1.9 \%)$ and the difference was statistically significant $\left(\chi^{2}=49.36 ; p=0.000\right)$ (Table 3). Anemia, low $5^{\text {th }}$ min Apgar score $(<7)$, low birth weight $(<2.5 \mathrm{~kg})$ and low occipitofrontal circumference were significantly higher in pregnancy with positive malaria parasitemia than women with negative malaria parasitemia. Anemia was significantly higher in rural women with positive malaria parasitemia $(47.7 \%)$ than urban women with positive malaria parasitemia $(32.4 \%)\left(\chi^{2}=4.06 ; p=0.044\right)$. Low birth weight was also, significantly higher in rural women with positive malaria parasitemia $(27.5 \%)$ than urban women with positive malaria parasitemia $(16.2 \%)\left(\chi^{2}=4.44 ; p=0.035\right)$.

\section{Discussion}

The prevalence of asymptomatic malaria parasitemia among pregnant women in the current study is $40.2 \%$. This percentage is similar to $41.6 \%$ reported in

Table 2: Obstetric outcome of patients with positive and negative placental malaria parasitization

\begin{tabular}{|c|c|c|c|c|c|c|}
\hline \multirow[t]{2}{*}{ Obstetrics Outcome } & \multicolumn{2}{|c|}{ Total $(n=440)$ Placenta parasitization } & \multirow[t]{2}{*}{$\chi^{2}(p-v a l u e)$} & \multicolumn{2}{|c|}{ Positive placenta parasitization $(n=309) n(\%)$} & \multirow[t]{2}{*}{$\chi^{2}$ (p-value) } \\
\hline & Positive (309) & Negative (131) & & Urban $(n=131)$ & Rural $(n=178)$ & \\
\hline \multicolumn{7}{|l|}{ Preterm delivery } \\
\hline Yes & $38(12.3)$ & $7(5.3)$ & \multirow[t]{2}{*}{$4.85(0.028)^{\star}$} & $17(13.0)$ & $21(11.8)$ & \multirow[t]{2}{*}{$0.10(0.755)$} \\
\hline No & $271(87.7)$ & $124(94.7)$ & & $114(87.0)$ & $157(88.2)$ & \\
\hline \multicolumn{7}{|l|}{ Anemia $(\mathrm{Hb}<11 \mathrm{~g} / \mathrm{dl})$} \\
\hline Yes & $69(22.3)$ & $21(16.0)$ & \multirow[t]{2}{*}{$2.24(0.134)$} & $16(12.2)$ & $53(29.8)$ & \multirow[t]{2}{*}{$13.42(0.000)^{*}$} \\
\hline No & $240(77.7)$ & $110(84.0)$ & & $115(87.8)$ & $125(70.2)$ & \\
\hline \multicolumn{7}{|l|}{ Stillbirth } \\
\hline Yes & $13(4.2)$ & $4(3.1)$ & \multirow[t]{2}{*}{$0.33(0.566)$} & $5(3.8)$ & $8(4.5)$ & \multirow[t]{2}{*}{$0.09(0.769)$} \\
\hline No & $296(95.8)$ & $127(96.9)$ & & $126(96.2)$ & $170(95.5)$ & \\
\hline \multicolumn{7}{|l|}{ Apgar score (5 min) } \\
\hline$<7$ & $51(16.5)$ & $11(8.4)$ & \multirow[t]{2}{*}{$5.0(0.025)^{*}$} & $10(7.6)$ & $41(23.0)$ & \multirow[t]{2}{*}{$12.99(0.000)^{*}$} \\
\hline$\geq 7$ & $258(83.5)$ & $120(91.6)$ & & $121(92.4)$ & $137(77.0)$ & \\
\hline \multicolumn{7}{|l|}{ Birth weight $(\mathrm{kg})$} \\
\hline$<2.5$ & $46(14.9)$ & $10(7.6)$ & \multirow[t]{2}{*}{$4.36(0.036)^{*}$} & $17(13.0)$ & $29(16.3)$ & \multirow[t]{2}{*}{$0.65(0.418)$} \\
\hline$\geq 2.5$ & $263(85.1)$ & $121(92.4)$ & & $114(87.0)$ & $149(83.7)$ & \\
\hline \multicolumn{7}{|c|}{ Occipitofrontal circumference } \\
\hline$<33 \mathrm{~cm}$ & $24(7.8)$ & $4(3.1)$ & \multirow[t]{2}{*}{$3.43(0.064)$} & $11(8.4)$ & $13(7.3)$ & \multirow[t]{2}{*}{$0.13(0.723)$} \\
\hline$>33$ & $285(92.2)$ & $127(96.9)$ & & $120(91.6)$ & $165(92.7)$ & \\
\hline \multicolumn{7}{|l|}{ Neonatal length } \\
\hline$<45 \mathrm{~cm}$ & $22(7.1)$ & $3(2.3)$ & \multirow[t]{2}{*}{$4.0(0.045)^{\star}$} & $10(7.6)$ & $12(6.7)$ & \multirow[t]{2}{*}{$0.09(0.763)$} \\
\hline$\geq 45 \mathrm{~cm}$ & $287(92.9)$ & $128(97.7)$ & & $121(92.4)$ & $166(93.3)$ & \\
\hline
\end{tabular}


Sokoto, northern Nigeria but lower than $68.3 \%$ reported in Markurdi and 92\% in Enugu [15], [16], [17]. However, it is higher than $7.7 \%$ reported in Lagos and $26 \%$ in Rivers state $[14,18]$. For placental parasitization, the prevalence is $70.2 \%$ which is considerably high. This percentage is higher than $65.2 \%$ reported in Port Harcourt, but lower than $90.8 \%$ in Abakaliki [19], [20]. The variation observed in the prevalence rates of malaria in the above highlighted studies could be attributed to the study area and method of testing for malaria parasite. Differences in predisposing factors to malaria infections such as the hot and humid climate that supports breeding of mosquito vectors, poor environmental conditions, anti-malarial drug resistance, maternal health access and compliance with preventive measures, poor drainage system and environmental sanitation may be responsible for the variation in prevalence rates of malaria parasitemia and placental parasitization [8], [19], [20]. The high prevalence of malaria parasitemia and placental parasitization observed in the current study may be attributable to the environment factors which proliferates the breeding site of mosquitoes in the study area thereby increasing pregnant women's vulnerability to repeated malaria exposure.

Based on residential status, rural residents $109(49.5 \%)$ had higher malaria parasitemia and higher placental parasitization 178 (80.9\%) than their urban counterparts (30.9\% for malaria parasitemia and $59.5 \%$ for placental parasitization) (Figures 1 and 2). This clearly suggests high malaria endemicity in rural areas. The high risk exposure to malaria among rural residents may be attributed to poor malaria preventive practices such as low use of insecticide treated nets (ITNs), insecticide spray, mosquito coil, insect repellants and presence of uncleared bushes around and within the house, overgrown grasses, presence of stagnant water and dirty environment which serve as breeding site for the female anopheles mosquito to proliferate and infect the susceptible host [20]. This may also, be due to the fact that urban residents have more awareness and engaged more in malaria prevention measures than their rural counterparts. High awareness and practice of malaria prevention may be responsible for lower prevalence of malaria among those with tertiary education in this study.

In the present study, malaria parasitemia was higher among the age group of 30-39 years than those of other age groups. This finding agrees with Adefioye et al. where old pregnant women of 36-39 years recorded the highest frequency rate of malaria [21]. The finding disagrees with a study in southeast Nigeria where malaria parasitemia was highest in 18-25 years old pregnant women [22]. For placental parasitization, pregnant women between 20 and 29 years of age recorded higher prevalence than those of other age groups. It is believed that younger pregnant mothers are more susceptible to malaria infection than their older counterparts because they are usually in their first pregnancy at earlier age with diminished immune system for malaria infection during pregnancy. The older pregnant women tends to have stronger immune system due to their repeated exposure to malaria bouts, development of immunity to malaria infection, previous personal experience and measures they adopt to prevent malaria [23].

Anemia, preterm delivery, low $5^{\text {th }}$ min Apgar score and low birth weight of $<2.5 \mathrm{~kg}$ were significantly higher among women with positive malaria parasitemia. This finding is congruent with a study carried out in Ibadan where low birth weight and anemia were highest among mothers positive for malaria parasitemia [24]. This result suggests that malaria parasitemia largely determines neonatal outcome. It can be hypothesized that the higher the rate of malaria transmission among pregnant women; the more neonates are susceptible to lower birth weight, low Apgar score, and preterm delivery. This argument supports existing evidencebased studies where maternal anemia could lead to fetal growth impairment, intrauterine growth restriction and low birth weight [4], [20]. Hence, prompt detection and treatment of malaria cases could boost better

Table 3: Obstetric outcome of patients with positive and negative malaria parasitemia

\begin{tabular}{|c|c|c|c|c|c|c|}
\hline \multirow[t]{2}{*}{ Obstetric Outcome } & \multicolumn{2}{|c|}{ Total $(n=440)$ Malaria parasitemia } & \multirow[t]{2}{*}{$\chi^{2}$ (p-value) } & \multicolumn{2}{|c|}{ Positive malaria parasitemia $(n=177)$} & \multirow[t]{2}{*}{$\chi^{2}(p$-value $)$} \\
\hline & Positive (177) & Negative (263) & & Urban $(n=68)$ & Rural $(n=109)$ & \\
\hline \multicolumn{7}{|l|}{ Preterm delivery } \\
\hline Yes & $40(22.6)$ & $5(1.9)$ & \multirow{2}{*}{$49.36(0.000)^{*}$} & $19(27.9)$ & $21(19.3)$ & \multirow{2}{*}{$1.80(0.179)$} \\
\hline No & $137(77.4)$ & $258(98.1)$ & & $49(72.1)$ & $88(80.7)$ & \\
\hline \multicolumn{7}{|c|}{ Anemia $(\mathrm{Hb}<11 \mathrm{~g} / \mathrm{dl})$} \\
\hline Yes & $74(41.8)$ & $16(6.1)$ & \multirow[t]{2}{*}{$82.98(0.000)^{*}$} & $22(32.4)$ & $52(47.7)$ & \multirow[t]{2}{*}{$4.06(0.044)^{*}$} \\
\hline No & $103(58.2)$ & $247(93.9)$ & & $46(67.6)$ & $57(52.3)$ & \\
\hline \multicolumn{7}{|l|}{ Stillbirth } \\
\hline Yes & $10(5.6)$ & $7(2.7)$ & \multirow[t]{2}{*}{$2.54(0.111)$} & $3(4.4)$ & $7(6.4)$ & \multirow[t]{2}{*}{$0.32(0.573)$} \\
\hline No & $167(94.4)$ & $256(97.3)$ & & $65(95.6)$ & $102(93.6)$ & \\
\hline \multicolumn{7}{|l|}{ Apgar score (5 min) } \\
\hline$<7$ & $48(27.1)$ & $14(5.3)$ & \multirow[t]{2}{*}{$41.52(0.000)^{*}$} & $21(30.9)$ & $27(24.8)$ & \multirow[t]{2}{*}{$0.79(0.374)$} \\
\hline$\geq 7$ & $129(72.9)$ & $249(94.7)$ & & $47(69.1)$ & $82(75.2)$ & \\
\hline \multicolumn{7}{|l|}{ Birth weight $(\mathrm{kg})$} \\
\hline$<2.5$ & $41(23.2)$ & $15(5.7)$ & \multirow[t]{2}{*}{$29.04(0.000)^{*}$} & $10(16.2)$ & $31(27.5)$ & \multirow[t]{2}{*}{$4.44(0.035)^{*}$} \\
\hline$\geq 2.5$ & $136(76.8)$ & $248(94.3)$ & & $58(83.8)$ & $78(72.5)$ & \\
\hline \multicolumn{7}{|c|}{ Occipitofrontal circumference } \\
\hline$<33 \mathrm{~cm}$ & $21(11.9)$ & $7(2.7)$ & \multirow[t]{2}{*}{$15.04(0.000)$ * } & $8(11.8)$ & $13(11.9)$ & \multirow[t]{2}{*}{$0.04(0.836)$} \\
\hline$\geq 33 \mathrm{~cm}$ & $156(88.1)$ & $256(97.3)$ & & $60(88.2)$ & $96(88.1)$ & \\
\hline \multicolumn{7}{|l|}{ Neonatal length } \\
\hline$<45 \mathrm{~cm}$ & $14(7.9)$ & $11(4.2)$ & \multirow[t]{2}{*}{$2.74(0.098)$} & $6(8.8)$ & $8(7.3)$ & \multirow[t]{2}{*}{$0.13(0.722)$} \\
\hline$\geq 45$ & $163(92.1)$ & $252(95.8)$ & & $62(91.2)$ & $101(92.7)$ & \\
\hline
\end{tabular}


neonatal outcome as well as improve the quality of life of babies.

On the other hand, preterm delivery was higher among pregnant women with positive placental parasitization than pregnant women with negative placental parasitization, and the difference was statistically significant. Preterm delivery was higher in rural area than the urban area. Low $5^{\text {th }}$ min Apgar score $(<7)$, low birth weight $(<2.5 \mathrm{~kg})$, and low neonatal length $(<45 \mathrm{~cm})$ were significantly higher in pregnancy with positive placental parasitization. This findings clearly indicates that malaria parasitization exert a substantial adverse influence on pregnancy outcome. Malaria parasite infection of the placenta causes necrosis of villous tissue and inflammation of the intervillous spaces [25]. Histological changes found in Plasmodiuminfected placentas include syncytial knotting, rupture and barrier thickening [25]. Consequently, spiral arteries become poorly formed leading to impaired delivery of maternal blood to the placenta, with resultant deprivation of oxygen required for fetal growth and development. These may be the reason for poor obstetrics outcome of low $5^{\text {th }}$ min Apgar score, low birth weight, and low neonatal length observed in pregnant women with positive placental malaria parasitization in this study. Poor adherence to treatment regimen and poor malaria prevention practices may reasonably account for high placental malaria parasitization and the observed complications [26].

\section{Conclusion}

The high rate of asymptomatic malaria parasitemia $(40.2 \%)$ and placental parasitization $(70.2 \%)$ in this study showed that Malaria in pregnancy is a major public health problem in Cross River state, Nigeria. Based on this findings, ITNs and other malaria preventive measures such as insecticide spray, insect repellant, mosquito coil, etc., should be distributed free of charges to pregnant women during antenatal care visits and mostly in rural areas where malaria burden is higher. This would heighten the uptake of malaria preventive practices. Planned urbanization with good drainage system and sanitation will reduce malaria effect. Recommended intermittent preventive treatment drug should be distributed to all health care facilities at all levels of health care free especially at the primary health care level and should be taken at the health facility under the supervision of health worker (Directly Observed Therapy). Improvement on female education, economic empowerment of women and promotion of gender equality will help women to improve on their social status, make informed decision concerning malaria prevention strategies and discard wrong socio-cultural beliefs.

\section{References}

1. Heinemann M, Phillips RO, Vinnemeier CD, Rolling CC, Tannich E and Rolling T. High prevalence of asymptomatic malaria infections in adults, Ashanti Region, Ghana, 2018. Malar J. 2020;19:366. https://doi.org/10.1186/s12936-020-03441-z PMid:33046056

2. Kassebaum NJ, Bertozzi-Villa A, Coggeshall MS, Shackelford KA, Steiner C, Heuton KR, et al. Global, regional, and national levels and causes of maternal mortality during 1990-2013: A systematic analysis for the global burden of disease study 2013. Lancet. 2014;384(9947):980-1004. https:// doi.org/10.1016/S0140-6736(14)60696-6

PMid:24797575

3. Rouamba $T$, Samadoulougou $S$, Ouédraogo $M$, Hien $H$ Tinto $\mathrm{H}$. Asymptomatic malaria and anaemia among pregnant women during high and low malaria transmission seasons in Burkina Faso: Household-based cross-sectional surveys in Burkina Faso, 2013 and 2017. Malar J. 2021;20:211. https://doi. org/10.1186/s12936-021-03703-4

PMid:33933072

4. Cottrell G, Moussiliou A, Luty AJ, Cot M, Fievet N, Massougbodji A, et al. Submicroscopic plasmodium falciparum infections are associated with maternal anemia, premature births, and low birth weight. Clin Infect Dis. 2015;60(10):1481-8. https://doi.org/10.1093/cid/civ122

PMid:25694651

5. McDonald CR, Elphinstone RE, Kain KC. The impact of placental malaria on neurodevelopment of exposed infants: A role for the complement system? Trends Parasitol. 2013;29(5):213-9. https://doi.org/10.1016/j.pt.2013.03.005 PMid:23562777

6. Ayoola OO, Gemmell I, Omotade OO, Adeyanju OA Cruickshank JK, Clayton PE. Maternal malaria, birth size and blood pressure in Nigerian newborns: Insights into the developmental origins of hypertension from the lbadan growth cohort. PLoS One. 2011;6(9):e24548. https://doi.org/10.1371/ journal.pone. 0024548

PMid:21931749

7. Huynh BT, Cottrell G, Cot M, Briand V. Burden of malaria in early pregnancy: A neglected problem? Clin Infect Dis. 2015;60(4):598-604. https://doi.org/10.1093/cid/ciu848

PMid:25362205

8. Kinney MV, KerberKJ, BlackRE, Cohen B, Nkrumah F, CoovadiaH, et al. Sub-Saharan Africa's mothers, newborns, and children: Where and why do they die. PLoS Med. 2010;7(6):e1000294. https://doi.org/10.1371/journal.pmed.1000294 PMid:20574524

9. Cohen JM, Smith DL, Cotter C, Ward A, Yamey G, Sabot OJ, et al. Malaria resurgence: A systematic review and assessment of its causes. Malar J. 2012;11(1):122. https://doi. org/10.1186/1475-2875-11-122

PMid:22531245

10. Mlugu EM, Minzi O, Kamuhabwa AAR, Aklillu E. Prevalence and correlates of asymptomatic malaria and anemia on first antenatal care visit among pregnant women in southeast, Tanzania. Int J Environ Res Public Health. 2020;17(9):3123. https://doi.org/10.3390/ijerph17093123 PMid:32365839

11. Akaba GO, Otubu JA, Agida ET, Onafowokan O. Knowledge and utilization of malaria preventive measures among pregnant women at a tertiary hospital in Nigeria's federal capital territory. Niger J Clin Pract. 2013;16(2):201-6. https://doi. org/10.4103/1119-3077.110162 


\section{PMid:23563462}

12. Hounton S, De Bernis L, Hussein J, Graham WJ, Danel I, Byass $\mathrm{P}$, et al. Towards elimination of maternal deaths: Maternal deaths surveillance and response. Reprod Health. 2013;10:1. https://doi.org/10.1186/1742-4755-10-1 PMid:23279882

13. Olofintoye $\mathrm{O}$, Sule $\mathrm{B}$. Impact of global warming on the rainfall and temperature in the Niger delta of Nigeria. J Res Inform Civil Eng. 2010;7(2):33-48.

14. Wogu MN, Nduka FO, Wogu MD. Prevalence of malaria parasite infection among pregnant women attending antenatal clinics in port Harcourt, Rivers state, Nigeria. Int J Trop Dis Health. 2013;3(2):126-32. https://doi.org/10.9734/IJTDH/2013/2738

15. Fana SA, Bunza MD, Anka SA, Imam AU, Nataala SU. Prevalence and risk factors associated with malaria infection among pregnant women in a semi-urban community of northwestern Nigeria. Infect Dis Poverty. 2015;4(1):24. https://doi. org/10.1186/s40249-015-0054-0

PMid:26269742

16. Amuta E, Houmsou R, Wama E, Ameh M. Malarial infection among antenatal and maternity clinics attendees at the Federal Medical Centre, Makurdi, Benue state, Nigeria. Infect Dis Rep. 2014;6(1):5050. https://doi.org/10.4081/idr.2014.5050 PMid:24757507

17. Ugwu EO, Dim CC, Uzochukwu BS, Iloghalu EI, Ugwu AO Malaria and anaemia in pregnancy: A cross-sectional study of pregnant women in rural communities of Southeastern Nigeria. Int Health. 2014;6(2):130-7. https://doi.org/10.1093/inthealth/ ihu009

PMid:24664630

18. Agomo CO, Oyibo WA. Factors associated with risk of malaria infection among pregnant women in Lagos, Nigeria. Infect Dis Poverty. 2013;2(1):19. https://doi.org/10.1186/2049-9957-2-19 PMid:24001135

19. Bassey G, Nyengidiki TK, John CT. Prevalence of placenta Plasmodium parasitemia and pregnancy outcome in asymptomatic patients at delivery in a university teaching hospital in Nigeria. Niger J Clin Pract. 2015;18(1):27-32. https:// doi.org/10.4103/1119-3077.146975

PMid:25511340

20. Nwali MI, Umeora OU, Ozumba BC, Onoh RC, Agwu UM, Agboeze J. Outcomes of asymptomatic malaria parasitaemia in neonates in a tertiary hospital, southeast Nigeria. Niger Med J. 2014;55(3):250-3. https://doi.org/10.4103/0300-1652.132063 PMid:25013259

21. Adefioye OA, Adeyeba OA, Hassan WO, Oyeniran OA Prevalence of malaria parasite infection among pregnant women in Osogbo, Southwest, Nigeria. Am Eurasian J Sci Res. 2007;2(1):43-5

22. Ivoke N, Ivoke ON, Okereke NC, Eyo JE. Falciparum malaria parasitaemia among pregnant women attending antenata clinics in a Guinea-Savannah zone, Southwestern Ebonyi state, Nigeria. Int J Sci Eng Res. 2013;4(9):1876-83.

23. Beeson $\mathrm{J}$. The immunology and pathogenesis of malaria during pregnancy. In: Beeson J, Duffy P, editors. Immunology and Immunopathogenesis of Malaria. $3^{\text {rd }}$ ed. Philadelphia, PA, USA: Springer; 2005. p. 197-227.

24. Falade $\mathrm{CO}$, Tongo OO, Ogunkunle OO, Orimadegun AE. Effects of malaria in pregnancy on newborn anthropometry. J Infect Dev Ctries. 2010;4(7):448-53. https://doi.org/10.3855/jidc.329 PMid:20818093

25. Souza RM, Ataide R, Dombrowski JG, Ippolito V, Aitken EH, Valle SN, et al. Placental histopathological changes associated with Plasmodium vivax infection during pregnancy. PLoS Neg Trop Dis. 2013;7(2):e2071. https://doi.org/10.1371/journal. pntd.0002071 PMid:23459254

26. Babalola AS, Idowu OA, Sam-Wobo SO, Fabusoro E. Malaria infection at parturition in Abeokuta, Nigeria: Current status and pregnancy outcome. Malariaworld J. 2017;8:12.

PMid:34532235 